\title{
Investigasi Penerimaan dari Aplikasi E-learning \\ Menggunakan Technology Acceptance Model (TAM) 3 \\ Case Report : e-learning STMIK Rosma
}

\author{
Lila Setiyani* \\ Program Studi Sistem Informasi STMIK Rosma \\ Jl. Kertabumi No.62, Karawang Kulon, Kabupaten Karawang, Indonesia \\ lila.setiyani@dosen.rosma.ac.id

\section{Karya Suhada} \\ Program Studi Teknik Informatika STMIK Rosma \\ Jl. Kertabumi No.62, Karawang Kulon, Kabupaten Karawang, Indonesia \\ karya@rosma.ac.id

\section{Femmy Effendy} \\ Program Studi Sistem Informasi STMIK Rosma \\ Jl. Kertabumi No.62, Karawang Kulon, Kabupaten Karawang, Indonesia \\ Femmy.effendy@dosen.rosma.ac.id
}

Diterima: 09-02-2021

Disetujui: 16-06-2021

Dipublikasi: 30-06-2021

\begin{abstract}
ABSTRAK
Penelitian ini bertujuan untuk mengukur tingkat adopsi e-learning dari salah satu perguruan tinggi yang telah mengaplikasikan e-learning di masa COVID-19. Model TAM 3 dipilih untuk mengukur tingkat adopsi $e$-learning . Penelitian ini melibatkan 100 responden dari mahasiswa angkatan 2020 STMIK ROSMA. Hasil pengumpulan data dianalisis menggunakan Structural Equation Model (SEM) dengan bantuan software SmartPLS 3. Hasil uji hipotesis penelitian ini menunjukkan bahwa citra terbukti memiliki pengaruh positif terhadap persepsi kegunaan e-learning, kecemasan pengguna e-learning tidak terbukti memiliki pengaruh positif terhadap persepsi kemudahan pengguna $e$-learning, keyakinan diri terbukti memiliki pengaruh positif terhadap persepsi kemudahan pengguna $e$-learning, kondisi yang memfasilitasi pengguna $e$-learning tidak terbukti memiliki pengaruh positif terhadap persepsi kemudahan pengguna e-learning, kualitas hasil memiliki pengaruh positif terhadap persepsi kegunaan e-learning, niat penggunaan e-learning memiliki pengaruh positif terhadap pengadopsian $e$-learning, norma subjektif memiliki pengaruh positif terhadap citra $e$-learning, norma subjektif memiliki pengaruh positif terhadap niat penggunaan e-learning, norma subjektif tidak terbukti memiliki pengaruh positif terhadap niat penggunaan e-learning, persepsi kegunaan e-learning memiliki pengaruh positif terhadap niat penggunaan $e$ learning, persepsi kemudahan pengguna e-learning memiliki pengaruh positif terhadap niat penggunaan $e$ learning, persepsi kemudahan pengguna learning memiliki pengaruh positif terhadap persepsi pengguna $e$ learning, persepsi kesenangan memiliki pengaruh positif terhadap persepsi pengguna $e$-learning. Hasil penelitian ini dapat menjadi evaluasi bagi STMIK ROSMA dalam mengimplementasikan e-learning.
\end{abstract}

Kata Kunci:

Technology Acceptance Model; TAM; Adopsi; E-learning

\section{ABSTRACT}

This study aims to measure the level of e-learning adoption from a tertiary institution that has applied e-learning during the COVID-19 period. The TAM 3 model was chosen to measure the level of e-learning adoption. This study involved 100 respondents from students of the 2020 STMIK ROSMA class. The results of data collection were analyzed using the Structural Equation Model (SEM) with the help of SmartPLS 3 software. The results of 
this research hypothesis test indicate that image has a positive effect on the perceived usefulness of e-learning, anxiety of e-learning users is not proven to have a positive effect on perceived ease of use e-learning, selfconfidence is proven to have a positive influence on the perceived ease of e-learning users, conditions that facilitate e-learning users are not proven to have a positive effect on the perceived ease of e-learning users, the quality of results has a positive influence on the perceived usefulness of e-learning, intention to use e-learning has a positive influence on the adoption of e-learning, subjective norms have a positive effect on e-learning images, subjective norms have a positive effect on intention to use e-learning, subjective norms are not proven to have a positive effect on intention to use e-learning, the perceived usefulness of e-learning has a positive influence on the intention of using e-learning, the perceived ease of e-learning users has a positive influence on the intention to use e-learning, the perception of the ease of using e-learning has a positive influence on the perceptions of elearning users, the perception pleasure has a positive influence on the perceptions of e-learning users. The results of this study can be an evaluation for STMIK ROSMA in implementing e-learning.

Keywords:

Technology Acceptance Model; TAM; Adoption; E-learning 


\section{PENDAHULUAN}

Pandemi COVID-19 telah berdampak pada seluruh bidang, terutama bidang pendidikan. Proses pembelajaran dan pengajaran harus beradaptasi, dari tatap muka dalam kelas menjadi kelas virtual yang memanfaatkan teknologi video conference seperti google meet, zoom, dan lain - lain serta e-learning. E-learning sebagai platform pembelajaran atau pengajaran yang berbasis online (Goyal, 2012) yang mencakup segala bentuk komunikasi digital yang digunakan untuk menyampaikan informasi (Alqudah et al., 2020). Proses pembelajaran dan pengajaran STMIK ROSMA pada masa pandemi COVID-19 telah memanfaatkan e-learning. Pemanfaatan e-learning ini mendukung efektivitas pembelajaran dan pengajaran yang dilakukan oleh dosen dan mahasiswa. Penerimaan aplikasi $e$-learning oleh mahasiswa menjadi suatu pertimbangan dalam mengukur tingkat adopsi dari aplikasi tersebut. STMIK ROSMA telah mengimplementasikan penggunaan $e$-learning dalam proses pembelajaran dan pengajaran selama satu semester. Hal ini menarik peneliti untuk mengetahui tingkat adopsi $e$-learning oleh mahasiswa. Tingkat adopsi aplikasi dapat menjadi masukan bagi perguruan tinggi untuk terus meningkatkan layanan kepada mahasiswanya.

Ada banyak model yang digunakan untuk mengukur adopsi atau penerimaan dari sebuah aplikasi atau sistem informasi, salah satunya adalah Technology Acceptance Model (TAM). Davis mengemukakan bahwa TAM adalah model penerimaan teknologi yang menjelaskan sikap dan perilaku individu terhadap perangkat teknologi atau sistem (Davis, 1989). Menurut McFarland \& Hamilton (2006) dalam (Zheng \& Li, 2020) menjelasakan bahwa TAM adalah model penerimaan teknologi yang paling sederhana, paling mudah digunakan dan paling kuat yang mengusulkan dua variabel yaitu persepsi kemudahan pengguna dan persepsi kegunanan yang mempengaruhi sikap terhadap penggunaan aplikasi, sistem atau teknologi baru yang kemudian akhirnya mempengaruhi niat perilaku mereka dalam penggunaan teknologi tersebut. Berikut adalah perkembangan konstruk dari kerangka TAM :

Tabel 1. Konstruksi TAM

\section{TAM}

(Davis, 1989)

1. External Variables

2. Perceived usefulness

3. Perceived ease of use

4. Attitude towards using

5. Behavioral intention to use

6. Actual use syatem
TAM 2 (Venkatesh \& Davis, 2000)

1. Experience

2. Voluntariness

3. Perceived Usefulness yang dipengaruhi faktorfaktor : subjective norm, image, job relevance, output quality, result demonstrability

4. Perceived ease of use

5. Behavioral intention to use

6. Use behavior

\section{TAM 3}

(Venkatesh \& Bala, 2008)

1. Experience

2. Voluntariness

3. Perceived Usefulness yang dipengaruhi faktor-faktor : subjective norm, image, job relevance, output quality, result demonstrability

4. Perceived ease of use yang dipengaruhi oleh faktor- faktor : computer self-efficiency, perception of external control, computer anxiety, computer playfulness, perceived enjoyment, objective usability

5. Behavioral intention to use

6. Use behavior 


\section{E-learning}

E-learning adalah suatu model pembelajaran yang dibuat dalam format digital melalui perangkat elektronik. Tujuan dikembangkannya e-learning dalam sistem pembelajaran adalah sebagai sarana pendukung proses belajar mengajar dan peningkatan kualitas layanan kepada peserta didik (Shandyastini \& Novianti, 2016). E-learning berperan untuk melengkapi kelas konvensional (secara tatap muka) bukan menggantikan kelas konvensional (Saifuddin, 2017). Menurut Novak dalam (Balaji et al., 2016) dengan menggunakan e-learning dapat meningkatkan interaktivitas dan efisiensi belajar karena memberikan mahasiswa potensi yang lebih tinggi untuk berkomunikasi lebih banyak dengan dosen, rekan, dan mengakses lebih banyak materi pembelajaran. Metode $e$-learning kurang lebih sama dengan proses belajar-mengajar yang ada di sekolah konvensional (Nuryadi, 2018). Menurut Suyanto (2005) dalam (Yulianingsih, 2016) E-learning mempunyai ciri atau karakteristik sendiri yang merupakan ciri khas dari e-learning itu sendiri. Karakteristik e-learning tesebut antara lain adalah:

1. Memanfaatkan jasa teknologi elektronik; dimana dosen dan mahasiswa, mahasiswa dan sesama mahasiswa atau dosen dan sesama dosen dapat berkomunikasi dengan relative mudah dengan tanpa dibatasi oleh hal hal yang protokoler.

2. Memanfaatkan keunggulan komputer (digital media dan computer networks).

3. Menggunakan bahan ajar bersifat mandiri (self-learning materials) disimpan di komputer sehingga dapat diakses oleh guru dan siswa kapan saja dan di mana saja bila yang bersangkutan memerlukannya.

4. Memanfaatkan jadwal pembelajaran, kurikulum, hasil kemajuan belajar dan hal-hal yang berkaitan dengan administrasi pendidikan dapat dilihat setiap saat di komputer.

\section{Technology Acceptance Model (TAM)}

TAM adalah salah satu ekstensi yang paling berpengaruh dari teori aksi penalaran atau Theory of Reasoned Act (TRA) oleh Ajzen dan Fishbein. Model TAM oleh Davis, Bagozzi \& Warshaw pada tahun 1989 adalah model penerimaan pengguna dan penggunaan teknologi yang paling banyak digunakan. Ini dikembangkan oleh Fred Davis dan Richard Bagozzi (Suyanto \& Kurniawan, 2019). Tujuan utama TAM adalah untuk mendirikan dasar penelusuran pengaruh faktor eksternal terhadap kepercayaan, sikap (personalisasi), dan tujuan pengguna komputer. TAM menganggap bahwa dua keyakinan variabel perilaku utama dalam mengadopsi sisitem informasi, yaitu persepsi pengguna terhadap manfaat (perceived usefulness) dan persepsi pengguna terhadap penggunaan (perceived ease of use) (Elhadi \& Kuryanti, 2020).

Penelitian ini dilakukan dengan menggunakan pendekatan Technology Acceptance Model 3 (TAM 3). Berdasarkan uraian mengenai literatur di atas, maka dapat disajikan model penelitian sebagai berikut: 


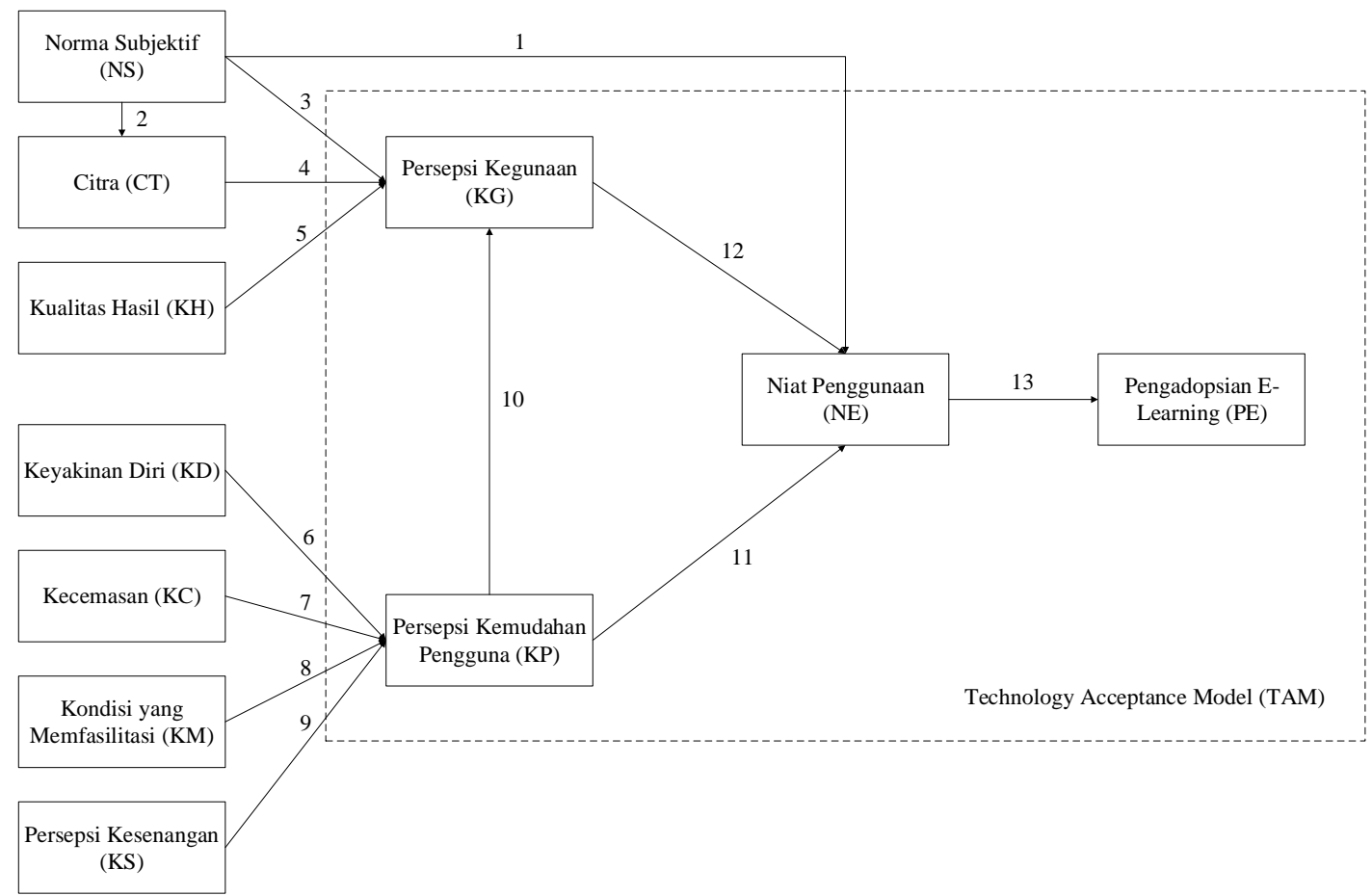

Gambar 1. Model Penelitian

Sumber: Venkatesh \& Bala, 2008

Adapun Hipotesis pada penelitian ini yaitu:

Tabel 2. Hipotesis Penelitian

\begin{tabular}{cl}
\hline Hipotesis & \multicolumn{1}{c}{ Keterangan } \\
\hline H1 & Citra berpengaruh positif terhadap persepsi kegunaan. \\
H2 & Kecemasan berpengaruh positif terhadap persepsi kemudahan pengguna. \\
H3 & Keyakinan diri berpengaruh positif terhadap persepsi kemudahan pengguna. \\
H4 & Kondisi yang memfasilitasi berpengaruh positif terhadap persepsi kemudahan pengguna. \\
H5 & Kualitas hasil berpengaruh positif terhadap persepsi kegunaan. \\
H6 & Niat penggunaan berpengaruh positif terhadap pengadopsian e-learning. \\
H7 & Norma subjektif berpengaruh positif terhadap citra. \\
H8 & Norma subjektif berpengaruh positif terhadap niat penggunaan. \\
H9 & Norma subjektif berpengaruh positif terhadap persepsi kegunaan. \\
H10 & Persepsi kegunaan berpengaruh positif terhadap niat penggunaan. \\
H11 & Persepsi kemudahan pengguna berpengaruh positif terhadap niat penggunaan. \\
H12 & Persepsi kemudahan berpengaruh positif terhadap persepsi kegunaan. \\
H13 & Persepsi kesenangan berpengaruh positif terhadap persepsi kemudahan pengguna. \\
\hline
\end{tabular}

\section{METODE RISET}

Penelitian ini termasuk pada penelitian kuantitatif menurut (Sugiyono, 2015) adalah metode penelitian yang berdasarkan pada filsafat positivisme yang digunakan pada populasi atau sampel tertentu, pengumpulan data menggunakan instrument penelitian kuantitatif/statistik. Dalam pengukuran adopsi penerimaan e-learning ini, peneliti menggunakan kerangka TAM 3. Populasi dari penelitian ini adalah mahasiswa STMIK ROSMA angkatan tahun 2020. Sampel diambil menggunakan teknik sensus yaitu menggunakan seluruh populasi yaitu sebanyak 108 mahasiswa. Peneliti menyebarkan kuesioner (lampiran 1) kepada 108 mahasiswa, namun dari penyebaran tersebut, hanya 100 mahasiswa yang bersedia mengisi kuesioner. Hasil pengumpulan data diolah menggunakan SmartPLS, yang kemudian 
dianalisis secara deskriptif untuk diketahui faktor - faktor yang mendukung dan penghambat dari adopsi e-learning.

\section{HASIL PENELITIAN DAN PEMBAHASAN}

Berdasarkan hasil pengujian Inner Model (model struktural) yang meliputi output $r$-square, koefisien parameter dan t-statistik. Untuk melihat apakah suatu hipotesis itu dapat diterima atau ditolak diantaranya dengan memperhatikan nilai signifikansi antar konstrak, t-statistik, dan $p$-values. Pengujian hipotesis penelitian ini dilakukan dengan bantuan software SmartPLS (Partial Least Square) 3.0. Nilainilai tersebut dapat dilihat dari hasil bootstrapping. Rules of thumb yang digunakan pada penelitian ini adalah t-statistik >1,96 dengan tingkat signifikansi p-value 0,05 (5\%) dan koefisien beta bernilai positif. Nilai pengujian hipotesis penelitian ini dapat ditunjukan pada Tabel 3.

Tabel 3. Nilai T-Statistik

\begin{tabular}{|c|c|c|c|c|c|}
\hline & $\begin{array}{l}\text { Original Sample } \\
(\mathrm{O})\end{array}$ & $\begin{array}{c}\text { Sample Mean } \\
(M)\end{array}$ & $\begin{array}{c}\text { Standard Deviation } \\
\text { (STDEV) }\end{array}$ & $\begin{array}{c}\text { T Statistics } \\
(\mid \text { OSTDEV } \mid)\end{array}$ & $P$ Values \\
\hline $\mathrm{CT}>\mathrm{KG}$ & 0.196 & 0.196 & 0.089 & 2.203 & 0.028 \\
\hline $\mathrm{KC}->\mathrm{KP}$ & -0.147 & -0.146 & 0.088 & 1.672 & 0.095 \\
\hline KD $->\mathrm{KP}$ & 0.206 & 0.206 & 0.095 & 2.164 & 0.031 \\
\hline KM -> KP & 0.054 & 0.049 & 0.076 & 0.709 & 0.479 \\
\hline $\mathrm{KH} \rightarrow \mathrm{KG}$ & 0.343 & 0.342 & 0.085 & 4.053 & 0 \\
\hline $\mathrm{NE}->\mathrm{PE}$ & 0.729 & 0.731 & 0.053 & 13.875 & $\mathbf{0}$ \\
\hline $\mathrm{NS} \rightarrow \mathrm{CT}$ & 0.537 & 0.546 & 0.073 & 7.373 & 0 \\
\hline NS $->$ NE & 0.284 & 0.284 & 0.061 & 4.652 & 0 \\
\hline NS $->$ KG & 0.167 & 0.164 & 0.103 & 1.62 & 0.106 \\
\hline $\mathrm{KG} \rightarrow \mathrm{NE}$ & 0.258 & 0.262 & 0.086 & 3.016 & 0.003 \\
\hline $\mathrm{KP} \rightarrow \mathrm{NE}$ & 0.459 & 0.454 & 0.095 & 4.807 & 0 \\
\hline $\mathrm{KP} \rightarrow \mathrm{KG}$ & 0.296 & 0.306 & 0.101 & 2.922 & 0.004 \\
\hline $\mathrm{KS}$-> KP & 0.575 & 0.58 & 0.074 & 7.803 & o \\
\hline
\end{tabular}

Hipotesis pertama menguji apakah Citra secara positif berpengaruh terhadap persepsi kegunaan $e$-learning. Hasil pengujian menunjukkan nilai koefisien beta citra terhadap persepsi kegunaan $e$ learning sebesar 0,196 dan t-statistik yaitu sebesar 2,203. Dari hasil ini dinyatakan t-statistik signifikan. karena $>1,96$ dengan $\mathrm{p}$-value $<0,05$ sehingga hipotesis pertama diterima. Hal tersebut membuktikan bahwa citra terbukti memiliki pengaruh positif terhadap persepsi kegunaan e-learning.

Hipotesis kedua menguji apakah kecemasan pengguna secara positif berpengaruh terhadap persepsi kemudahan pengguna e-learning. Hasil pengujian menunjukkan nilai koefisien beta kecemasan pengguna e-learning terhadap persepsi kemudahan pengguna sebesar - 0,147 dan t-statistik yaitu sebesar 1,672. Dari hasil ini dinyatakan t-statistik tidak signifikan. karena <1,96 dengan p-value $<0,05$ sehingga hipotesis kedua ditolak. Hal tersebut membuktikan bahwa kecemasan pengguna $e$ learning tidak terbukti memiliki pengaruh positif terhadap persepsi kemudahan pengguna e-learning.

Hipotesis ketiga menguji apakah keyakinan diri dalam menggunakan e-learning secara positif berpengaruh terhadap persepsi kemudahan pengguna e-learning. Hasil pengujian menunjukkan nilai koefisien beta keyakinan diri terhadap persepsi kemudahan pengguna e-learning sebesar 0,206 dan tstatistik yaitu sebesar 2,164. Dari hasil ini dinyatakan t-statistik signifikan. karena >1,96 dengan p-value 
$<0,05$ sehingga hipotesis ketiga diterima. Hal tersebut membuktikan bahwa keyakinan diri terbukti memiliki pengaruh positif terhadap persepsi kemudahan pengguna e-learning.

Hipotesis keempat menguji apakah kondisi yang memfasilitasi pengguna e-learning secara positif berpengaruh terhadap persepsi kemudahan pengguna e-learning. Hasil pengujian menunjukkan nilai koefisien beta kondisi yang memfasilitasi pengguna e-learning terhadap persepsi kemudahan pengguna sebesar 0,054 dan t-statistik yaitu sebesar 0,709. Dari hasil ini dinyatakan t-statistik tidak signifikan. karena $<1,96$ dengan p-value $<0,05$ sehingga hipotesis keempat ditolak. Hal tersebut membuktikan bahwa kondisi yang memfasilitasi pengguna $e$-learning tidak terbukti memiliki pengaruh positif terhadap persepsi kemudahan pengguna e-learning.

Hipotesis kelima menguji apakah kualitas hasil dalam menggunakan e-learning secara positif berpengaruh terhadap persepsi kegunaan e-learning. Hasil pengujian menunjukkan nilai koefisien beta kualitas hasil terhadap persepsi kegunaan e-learning sebesar 0,343 dan t-statistik yaitu sebesar 4,053. Dari hasil ini dinyatakan t-statistik signifikan. karena $>1,96$ dengan $\mathrm{p}$-value $<0,05$ sehingga hipotesis kelima diterima. Hal tersebut membuktikan bahwa kualitas hasil memiliki pengaruh positif terhadap persepsi kegunaan e-learning.

Hipotesis keenam menguji apakah niat penggunaan e-learning secara positif berpengaruh terhadap pengadopsian e-learning. Hasil pengujian menunjukkan nilai koefisien beta niat penggunaan e-learning terhadap pengadopsian e-learning sebesar 0,729 dan t-statistik yaitu sebesar 13,875. Dari hasil ini dinyatakan t-statistik signifikan. karena $>1,96$ dengan $p$-value $<0,05$ sehingga hipotesis keenam diterima. Hal tersebut membuktikan bahwa niat penggunaan e-learning memiliki pengaruh positif terhadap pengadopsian e-learning.

Hipotesis ketujuh menguji apakah norma subjektif secara positif berpengaruh terhadap citra. Hasil pengujian menunjukkan nilai koefisien beta norma subjektif terhadap citra sebesar 0,537 dan tstatistik yaitu sebesar 7,373. Dari hasil ini dinyatakan t-statistik signifikan. karena >1,96 dengan p-value $<0,05$ sehingga hipotesis ketujuh diterima. Hal tersebut membuktikan bahwa norma subjektif memiliki pengaruh positif terhadap citra $e$-learning.

Hipotesis kedelapan menguji apakah norma subjektif secara positif berpengaruh terhadap niat penggunaan $e$-learning. Hasil pengujian menunjukkan nilai koefisien beta norma subjektif terhadap niat penggunaan e-learning sebesar 0,284 dan t-statistik yaitu sebesar 4,652. Dari hasil ini dinyatakan tstatistik signifikan. karena $>1,96$ dengan p-value $<0,05$ sehingga hipotesis kedelapan diterima. Hal tersebut membuktikan bahwa norma subjektif memiliki pengaruh positif terhadap niat penggunaan $e$ learning.

Hipotesis kesembilan menguji apakah norma subjektif secara positif berpengaruh terhadap niat penggunaan e-learning. Hasil pengujian menunjukkan nilai koefisien beta norma subjektif terhadap persepsi kegunaan e-learning sebesar 0,167 dan t-statistik yaitu sebesar 1,620. Dari hasil ini dinyatakan t-statistik tidak signifikan. karena $<1,96$ dengan $\mathrm{p}$-value $<0,05$ sehingga hipotesis kesembilan ditolak. 
Hal tersebut membuktikan bahwa norma subjektif tidak terbukti memiliki pengaruh positif terhadap niat penggunaan e-learning.

Hipotesis kesepuluh menguji apakah persepsi kegunaan e-learning secara positif berpengaruh terhadap niat penggunaan e-learning. Hasil pengujian menunjukkan nilai koefisien beta persepsi kegunaan e-learning terhadap niat penggunaan e-learning sebesar 0,258 dan t-statistik yaitu sebesar 3,160. Dari hasil ini dinyatakan t-statistik signifikan. karena $>1,96$ dengan $\mathrm{p}$-value $<0,05$ sehingga hipotesis kesepuluh diterima. Hal tersebut membuktikan bahwa persepsi kegunaan e-learning memiliki pengaruh positif terhadap niat penggunaan e-learning.

Hipotesis kesebelas menguji apakah persepsi kemudahan pengguna e-learning secara positif berpengaruh terhadap niat penggunaan e-learning. Hasil pengujian menunjukkan nilai koefisien beta persepsi kemudahan pengguna e-learning terhadap niat penggunaan e-learning sebesar 0,459 dan tstatistik yaitu sebesar 4,807. Dari hasil ini dinyatakan t-statistik signifikan. karena >1,96 dengan p-value $<0,05$ sehingga hipotesis kesebelas diterima. Hal tersebut membuktikan bahwa persepsi kemudahan pengguna $e$-learning memiliki pengaruh positif terhadap niat penggunaan $e$-learning.

Hipotesis keduabelas menguji apakah persepsi kemudahan pengguna e-learning secara positif berpengaruh terhadap persepsi kegunaan e-learning. Hasil pengujian menunjukkan nilai koefisien beta persepsi kemudahan pengguna $e$-learning terhadap persepsi pengguna $e$-learning sebesar 0,296 dan tstatistik yaitu sebesar 2,922. Dari hasil ini dinyatakan t-statistik signifikan. karena $>1,96$ dengan p-value $<0,05$ sehingga hipotesis keduabelas diterima. Hal tersebut membuktikan bahwa persepsi kemudahan pengguna learning memiliki pengaruh positif terhadap persepsi pengguna $e$-learning .

Hipotesis ketigabelas menguji apakah persepsi kesenangan secara positif berpengaruh terhadap persepsi kemudahan pengguna e-learning. Hasil pengujian menunjukkan nilai koefisien beta persepsi kesenangan terhadap persepsi pengguna e-learning sebesar 0,575 dan t-statistik yaitu sebesar 7,803. Dari hasil ini dinyatakan t-statistik signifikan, karena $>1,96$ dengan p-value $<0,05$ sehingga hipotesis ketigabelas diterima. Hal tersebut membuktikan bahwa persepsi kesenangan memiliki pengaruh positif terhadap persepsi pengguna $e$-learning.

\section{KESIMPULAN DAN SARAN}

Penelitian ini bertujuan untuk menganalisis penerimaan dari aplikasi e-learning dengan menggunakan TAM (Technology Acceptance Model) pada seluruh mahasiswa/i STMIK Rosma Karawang. Model yang digunakan dalam penelitian ini adalah model TAM 3 pada aplikasi e-learning. Berdasarkan penelitian yang telah dilakukan maka dapat diambil kesimpulan-kesimpulan sebagai berikut:

1. Citra secara positif berpengaruh terhadap persepsi kegunaan e-learning. Hal ini mengindikasikan bahwa jika suatu sistem dirasakan kegunaan atau manfaatnya, maka citra yang akan terbentuk ketika menggunakan e-learning menjadi tolak ukur pengguna. 
2. Kecemasan pengguna secara negatif berpengaruh terhadap persepsi kemudahan pengguna $e$ learning. Jika pengguna merasa takut atau cemas ketika dihadapkan pada suatu teknologi, maka akan menyulitkan pengguna untuk menjalankan teknologi tersebut. Dalam penelitian ini menunjukkan bahwa pengguna tidak memiliki kecemasan atau ketakutan terhadap sistem $e$ learning, sehingga akan mempermudah mereka untuk mengoperasikan sistem tersebut.

3. Keyakinan diri dalam menggunakan e-learning secara positif berpengaruh terhadap persepsi kemudahan pengguna $e$-learning. Dengan adanya keyakinan diri dari pengguna bahwa mereka mampu untuk menggunakan e-learning dengan menfaatkan petunjuk cara penggunaannya, maka akan memberikan dampak positif terhadap kemudahan penggunaan e-learning.

4. Kondisi yang memfasilitasi pengguna e-learning secara negatif berpengaruh terhadap persepsi kemudahan pengguna e-learning. Dengan adanya fasilitas pendukung seperti tersedianya tutorial atau modul penggunaan e-learning, maka akan mempermudah pengguna untuk mengoperasikan e-learning.

5. Kualitas hasil dalam menggunakan e-learning secara positif berpengaruh terhadap persepsi kegunaan e-learning. Suatu sistem akan dirasakan kegunaan jika mampu memberikan output yang baik bagi penggunannya. E-learning merupakan suatu sistem yang disediakan untuk mempermudah pengguna dalam proses pembelajaran. Sehingga dengan adanya e-learning ini akan lebih mempermudah proses pembelajaran yang disampaikan oleh dosen dikarenakan sudah menggunakan sistem yang terkomputerisasi.

6. Niat penggunaan e-learning secara positif berpengaruh terhadap pengadopsian e-learning. Semakin tinggi niat pengguna untuk menggunakan e-learning maka akan mendorong mereka untuk menggunakannya secara nyata. Pengguna akan puas menggunakan e-learning jika mereka meyakini bahwa $e$-learning mudah untuk dioperasikan dan mendatangkan manfaat bagi mereka, yang dapat dilihat dari kondisi nyata penggunaan.

7. Norma subjektif secara positif berpengaruh terhadap citra dan niat penggunaan, dan norma subjektif berpengaruh negatif persepsi kegunaan e-learning. Dengan adanya dorongan dari orang disekitar pengguna untuk menggunakan e-learning, maka akan meyakini pengguna akan manfaat dari e-learning, sehingga menimbulkan niat untuk menggunakan e-learning. Selanjutnya, norma subjektif juga berpengaruh positif terhadap citra. Hal ini mengindikasikan bahwa dengan adanya kebijakan atau dorongan untuk menggunakan sistem, maka akan membentuk citra pengguna. Sedangkan, norma subjektif berpengaruh negatif terhadap persepsi kegunaan e-learning. mengindikasikan bahwa dengan adanya kebijakan atau dorongan untuk menggunakan sistem, ternyata tidak mempengaruhi pengguna terhadap kegunaan $e$-learning.

8. Persepsi kegunaan $e$-learning secara positif berpengaruh terhadap niat penggunaan $e$-learning Semakin e-learning berguna bagi pengguna, maka pengguna akan berniat untuk menggunakan e-learning tersebut. 
9. Persepsi kemudahan pengguna $e$-learning secara positif berpengaruh terhadap niat penggunaan dan persepsi kegunaan e-learning. Pengguna berniat untuk menggunakan e-learning karena mereka merasa menggunakan e-learning itu mudah. Kemudahan yang dirasakan inilah yang mempengaruhi pengguna terhadap manfaat atau kegunaan e-learning.

10. Persepsi kesenangan secara positif berpengaruh terhadap persepsi kemudahan pengguna $e$ learning. E-learning merupakan sistem berbasis online yang dapat diakses oleh pengguna dimana pun dan kapan pun $(24 \times 7)$ melalui perangkat smartphone ataupun laptop/komputer pengguna. Sehingga memberikan rasa senang dan nyaman bagi pengguna karena akan lebih mempermudah mereka untuk menyampaikan materi pembelajaran, tanpa perlu repot datang ke kampus untuk menyampaikannya. 


\section{DAFTAR PUSTAKA}

Alqudah, N. M., Jammal, H. M., Saleh, O., Khader, Y., Obeidat, N., \& Alqudah, J. (2020). Perception and experience of academic Jordanian ophthalmologists with E-learning for undergraduate course during the COVID-19 pandemic. Annals of Medicine and Surgery, 59(June), 44-47. https://doi.org/10.1016/j.amsu.2020.09.014

Balaji, D. R., Al-Mahri, F. A., \& Balaji, M. (2016). A Perspective Study on Content Management in Elearning and M-Learning. http://arxiv.org/abs/1605.02093

Davis, F. D. (1989). Perceived usefulness, perceived ease of use, and user acceptance of information technology. MIS Quarterly: Management Information Systems, 13(3), 319-339. https://doi.org/10.2307/249008

Elhadi, H., \& Kuryanti, S. J. (2020). Analisa Penggunaan Jangkauan Siar Televisi Dakwah Dengan Menggunakan Pendekatan Technology Acceptance Model (TAM). JUSIM (Jurnal Sistem Informasi Musirawan), 05(01), 13-18.

Goyal, S. (2012). E-learning: Future of Education. Journal of Education and Learning (EduLearn), 6(4), 239. https://doi.org/10.11591/edulearn.v6i4.168

Nuryadi, N. (2018). Rancang Bangun Aplikasi Website E-learning Pada Smk Respati 1 Jakarta. 4(1), $162-166$.

Saifuddin, M. F. (2017). E-learning Dalam Persepsi Mahasiswa. Jurnal Varidika, 29(2), 102-109.

Shandyastini, N. M., \& Novianti, K. D. P. (2016). Analisis E-learning Stmik Stikom Bali Menggunakan Techonology Acceptance Model. Jurnal TEKNOIF, 4(2), 1-6.

Sugiyono. (2015). Metode Penelitian Kombinasi (Mix Methods). Alfabeta.

Suyanto, \& Kurniawan, T. A. (2019). Faktor yang Mempengaruhi Tingkat Kepercayaan Penggunaan Fintech pada UMKM dengan Menggunakan Teknologi Acceptance Model (TAM). Jurnal Akuntansi Dan Manajemen Akmenika, 16(1), 175-186. https://journal.upy.ac.id/index.php/akmenika/article/view/166

Venkatesh, V., \& Bala, H. (2008). Technology acceptance model 3 and a research agenda on interventions. Decision Sciences, 39(2), 273-315. https://doi.org/10.1111/j.1540$\underline{5915.2008 .00192 . x}$ 
Yulianingsih, E. (2016). Analisis Kepuasan Terhadap Penggunaan E-learning Menggunakan Technology Acceptance Model Dan End User Computing Satisfaction. Jurnal Ilmiah Matrik, 18(1), 27-42. https://doi.org/10.33557/jurnalmatrik.v18i1.396

Zheng, J., \& Li, S. (2020). What drives students' intention to use tablet computers: An extended technology acceptance model. International Journal of Educational Research, 102(May). https://doi.org/10.1016/j.ijer.2020.101612. 